\title{
Adherence and Its Associated Factors Among Adult HIV-Infected Patients on Antiretroviral Therapy in South Western Ethiopia, 2020
}

This article was published in the following Dove Press journal: Patient Preference and Adherence

\section{Abiy Tadesse Angelo \\ Daniel Shiferaw Alemayehu (ID}

Department of Nursing, Mizan Tepi University, Mizan Aman, Ethiopia
Correspondence: Abiy Tadesse Angelo Email abiyutad@gmail.com
Background: Good adherence to antiretroviral therapy (ART) suppresses the viral load, reconstitutes the immune system, and decreases opportunistic infections among HIV-positive patients. However, adherence to ART is still challenging in developing countries such as Ethiopia. The study, therefore, aimed to assess adherence and its associated factors among HIV-positive patients on ART in southern Ethiopia in 2020.

Materials and Methods: A cross-sectional study was conducted among 329 randomly selected participants. A structured questionnaire was used to collect the data through a face-to-face interview from January 23 to February 23, 2020. Data were entered into Epidata 3.1 and exported to SPSS version 21 for analysis. Bivariate and multivariate logistic regressions were used for analysis. A $p$-value of less than 0.05 was considered significant in a multivariate logistic regression analysis. Results: In total, 274 patients (83.3\%) had good adherence to ART, while $16.7 \%$ did not adhere. Age between 39 and 49 years old $(\mathrm{AOR}=0.068,95 \%$ CI $0.008,0.578)$, urban residency $(\mathrm{AOR}=5.186,95 \% \mathrm{CI} 1.732,15.529)$, an educational status of being unable to read and write (AOR $=0.097,95 \%$ CI $0.012,0.771$ ), an educational status of reading and writing with no formal education $(\mathrm{AOR}=0.056,95 \% \mathrm{CI} 0.006,0.532)$, comorbidity $(\mathrm{AOR}=0.042,95 \% \mathrm{CI} 0.013,0.139)$, disclosure $(\mathrm{AOR}=3.583,95 \% \mathrm{CI} 1.008,12.739)$, WHO clinical stage II (AOR $=0.098,95 \% \mathrm{CI}$ $0.021,0.453$ ), and CD4 count $\geq 500$ cells $/ \mathrm{mm}^{3}$ (AOR=5.634, 95\% CI 1.203, 26.383) were significantly associated with adherence to ART among patients.

Conclusion: The adherence of patients to ART is relatively low compared to other studies conducted in different regions. Age 39-49 years, educational status, comorbidity, and WHO clinical staging were negatively associated with ART adherence. Residency, disclosure, and current CD4 category greater than or equal to 500 cells $/ \mathrm{mm}^{3}$ were positively associated with adherence. Good counseling to patients from rural areas, with low educational status, and with low CD4 counts, and on the importance of disclosure, is recommended and should be given by professionals.

Keywords: adherence, southwestern Ethiopia, antiretroviral therapy

\section{Introduction}

Globally, about 37.9 million people are living with human immunodeficiency virus (HIV), among whom the largest proportion are adults, comprising 36.2 million. The emergence of HIV has taken a long time but the epidemic continues to grow and 1.7 million new infections were reported in 2018. A report from different regions indicated that there is worrying evidence of continued HIV-related mortality. ${ }^{1}$

Sub-Saharan African regions continue to have the highest incidences of HIV compared to other regions in the world. ${ }^{2}$ In 2018, about 800,000 new HIV 
infections were encountered in eastern and southern Africa. The deaths attributed to HIV in this region are considerable and significant, as there were 310,000 deaths in this region in 2018. There is a gap in the coverage of antiretroviral therapy (ART) in this region; for instance, the coverage in some countries is only $9 \%$. In this region, mortality is also attributed to the continued challenges in retaining adherence to ART. ${ }^{1}$ Ethiopia is one of the sub-Saharan African countries carrying the burden of HIV. In 2017, 722,248 adults were living with HIV. ${ }^{3}$

The initiation of a ART has significantly reduced the mortality of people living with human immunodeficiency virus (PLWHIV) by suppressing the viral load. ${ }^{2,4}$ Early initiation and strict adherence to the antiretroviral drugs by the patients are important in the reduction of the progression of the virus to the acquired immune deficiency syndrome (AIDS) state and improving the overall quality of life of the patient. ${ }^{5}$

Although there has been a dramatic change in the coverage of ART services across the globe to include low- and middle-income countries, there are still challenges in helping patients to adhere to their initiated antiretroviral drugs. ${ }^{6}$ Findings from North America showed that only $55 \%(n=17,573)$ of PLWHIV have an adherence level greater than $80 \%$. In Africa, meta-analysis data showed that $77 \%$ of patients adhered to their medication, by considering an $80 \%$ cut-off value. ${ }^{7}$

Factors associated with adherence to the initiated antiretroviral drugs include side effects of the medications, intention to disclose the condition to others, feeling of better health condition, and socio-economic status, including educational status, residence, and income. ${ }^{8-12}$

In developing countries such as Ethiopia, adherence by HIV-positive patients to their medication is challenging. ${ }^{13}$ Being non-adherent to the medication can cause numerous problems for HIV-positive patients, including disease progression, hospitalization, and death. Moreover, nonadherence can affect the community by facilitating the transmission of HIV. ${ }^{14,15}$ In the current study site, the adherence level of patients and its contributory factors have not been determined. Therefore, this study aimed to determine the adherence level and its factors in adult HIVpositive patients taking ART in southern Ethiopia in 2020.

\section{Materials and Methods}

\section{Study Setting and Design}

The study was conducted in Gebre-Tsadik Shawo General Hospital (GTSGH) and Mizan Tepi University Teaching
Hospitals (MTUTH). GTSGH is a governmental hospital located in Bonga, $452.54 \mathrm{~km}$ from Addis Ababa, the capital city of Ethiopia. At the time of data collection, there were 1409 adult HIV-positive patients receiving their antiretroviral medications in GTSGH. MTUTH is located $568.4 \mathrm{~km}$ from Addis Ababa. During the time of data collection, there were a total of 1629 adult HIVpositive patients receiving their antiretroviral medications in MTUTH. An institutional-based quantitative crosssectional study design was conducted from January 23 to February 23, 2020.

\section{Source Population}

The source population comprised adult HIV-positive patients following treatment at the ART clinics of MTUTH and GTSGH.

\section{Study Participants}

Study participants were sampled adult HIV-positive patients following treatment at the ART clinics of MTUTH and GTSGH during the time of data collection.

\section{Inclusion and Exclusion Criteria}

All adult HIV-positive patients following their treatment at the ART clinics of MTUTH and GTSGH during the time of data collection were included. Severely ill patients from other medical causes who were linked to the medical treatment department, and those aged less than 18 years old, were excluded from the study.

\section{Sample Size and Sampling Technique}

The sample size was determined using a single population proportion formula. Based on the assumption of a $95 \%$ confidence interval, a $5 \%$ margin of error, the proportion of adherence to ART being $73 \%,{ }^{16}$ and a $10 \%$ nonresponse rate, a total sample of 333 was needed.

A systematic random sampling method was used to select study participants. First, the source population in each hospital was identified; during the time of data collection, there was a total of 1629 adult HIV-positive patients taking antiretroviral drugs in MTUTH. Similarly, there was a total of 1409 adult HIV-positive patients taking antiretroviral drugs in GTSGH. To obtain 333 study participants, a proportional allocation was made to each hospital, and in that way, 179 samples were from MTUTH and 154 were from GTSGH. The sampling interval (K-th) for each hospital was determined by dividing the source population in each hospital into proportionally allocated 
samples in each hospital. For each hospital, the sampling interval (K-th) was 9. To obtain the first participant for the data collection, from 1 to 9 , number 3 was randomly selected, and on each day of data collection, the third attending patient was the starting point of data collection. On each day of data collection, the third patient was taken as the first sample, and then every ninth interval was taken to conduct an interview until the required sample size was acquired. In both settings, patients taking antiretroviral drugs are provided with their monthly medications and attend monthly appointments. Unless patients have contracted other medical illnesses, it is unlikely that they would visit the hospital before the due appointment date.

\section{Data Collection Tool, Quality Control, and Procedure}

The questionnaire for this study was developed based on previous relevant studies which were conducted in other parts of Ethiopia with a similar purpose. ${ }^{16,17}$ The structured questionnaire, which was first designed in English, was translated to the Amharic version, which is the local language, to make it clearer and easier to understand. The questionnaire had the following essential components: socio-demographic characteristics, clinical variables, and behavioral variables. A one-day orientation on data collection was given to four data-collector diploma nurses. Before actual data collection, the questionnaire was pretested on 17 patients attending Wacha primary hospital, a different hospital from the current study sites, and necessary corrections were made before using it for the actual study. The face-to-face interviews were conducted by four diploma nurses who collected the data.

ART adherence was measured by recording the total number of pills taken in one full month. ${ }^{18,19}$ In addition to recording the patient's report, data collectors checked the total number of pills that a patient had taken from a total of 30 pills, and cross-matching was done for checking purposes and to reduce potential recall bias. To determine the adherence level for each participant, the actual number of pills taken by a patient was divided by the total number of pills to be taken (30), which was then multiplied by $100 \%$. The adherence status was dichotomized to adherence to ART, if participants scored above or equal to $95 \%$, and otherwise non-adherence. ${ }^{20}$ Furthermore, participants who did not adhere were dichotomized to fair and poor adherence by taking $85 \%$ as the cut-off value. ${ }^{13,20}$

\section{Data Processing and Analysis}

Data were entered into Epidata 3.1 version after a manual check for completeness, skip pattern, and wrong coding, which was corrected at the study site. The entered data were exported to SPSS version 21 for analysis. Descriptive statistics using a table of frequency distribution were used to summarize the results, such as socio-demographic characteristics, and clinical and behavioral variables. Then, the data were presented using sentences, graphs, tables, frequencies, and percentages. Both bivariate and multivariate logistic regressions were used to identify the independent predictors of ART adherence. Crude odds ratios (CORs) were used to explain the strength of association between factors and dependent variables at $p<0.25$ for bivariate logistics, and adjusted odds ratios (AORs) were used to describe the strength of association between the factors and dependent variables in multivariate logistics at $p<0.05$.

\section{Ethical Considerations}

This study was conducted in accordance with the Declaration of Helsinki and a formal letter was obtained to conduct the study from the Nursing Department, Mizan Tepi University. The administration offices of both hospitals were informed about the purpose of the study to obtain permission. Confidentiality of the respondents was secured by excluding respondents' identifiers, such as names, from the data collection format. Informed written consent was obtained from the respondents before conducting the study.

\section{Results \\ Socio-Demographic Characteristics}

Out of 333 participants, 329 were involved in the study, making a response rate of $98.8 \%$. The mean age of the participants was 35.19 years, with the minimum of 18 years and maximum of 60 years old. The majority (43.8\%) of study participants were in the age category $28-$ 38 years old, while $171(52.0 \%)$ were females and $77.2 \%$ of them were from urban areas. Regarding the ethnicity, the majority (58.7) were Kaffa; 301 (91.5\%) were living with family, $47.1 \%$ had attended primary education, and the majority $(66.9 \%)$ were married (Table 1$)$.

\section{Clinical and Behavioral Characteristics of Participants}

The majority $(69.9 \%)$ of participants had no comorbid conditions, while $90 \%$ were in WHO clinical stage I and $45.9 \%$ had current cluster of differentiation 4 (CD4) levels 
Table I Socio-Demographic Characteristics of Patients Who Were on ART at GTSGH and MTUTH, Southwest Ethiopia, 2020

\begin{tabular}{|c|c|c|c|}
\hline \multicolumn{2}{|l|}{ Characteristics } & \multirow{5}{*}{$\begin{array}{l}\text { Frequency } \\
73 \\
144 \\
86 \\
26\end{array}$} & \multirow{5}{*}{$\begin{array}{l}\text { Percentage } \\
22.2 \\
43.8 \\
26.1 \\
7.9\end{array}$} \\
\hline Age category & $18-28$ & & \\
\hline & $29-39$ & & \\
\hline & $40-49$ & & \\
\hline & $\geq 50$ & & \\
\hline \multirow[t]{2}{*}{ Gender } & Male & 158 & 48.0 \\
\hline & Female & 171 & 52.0 \\
\hline \multirow[t]{4}{*}{ Marital status } & Single & 61 & 18.5 \\
\hline & Married & 220 & 66.9 \\
\hline & Divorced & 45 & 13.7 \\
\hline & Widowed & 3 & 0.9 \\
\hline \multirow{2}{*}{ Living with family } & Yes & 301 & 91.5 \\
\hline & No & 28 & 8.5 \\
\hline \multirow[t]{2}{*}{ Residence } & Urban & 254 & 77.2 \\
\hline & Rural & 75 & 22.8 \\
\hline \multirow[t]{5}{*}{ Educational status } & Cannot read and write & 57 & 17.3 \\
\hline & Able to read and write & 35 & 10.6 \\
\hline & Primary school & 155 & 47.1 \\
\hline & Secondary school & 57 & 17.3 \\
\hline & Higher education & 25 & 7.6 \\
\hline \multirow[t]{6}{*}{ Ethnicity } & Kaffa & 193 & 58.7 \\
\hline & Amhara & 57 & 17.3 \\
\hline & Oromo & 11 & 3.3 \\
\hline & Bench & 34 & 10.3 \\
\hline & Sheko & 12 & 3.6 \\
\hline & Others* & 22 & 6.7 \\
\hline \multirow[t]{4}{*}{ Religion } & Orthodox & 186 & 56.5 \\
\hline & Muslim & 52 & 15.8 \\
\hline & Protestant & 85 & 25.8 \\
\hline & Catholic & 6 & 1.8 \\
\hline \multirow{3}{*}{$\begin{array}{l}\text { Monthly income in } \\
\text { ETB }\end{array}$} & $<1000$ & 125 & 38.0 \\
\hline & $1000-3000$ & 122 & 37 \\
\hline & $>3000$ & 82 & 25 \\
\hline \multirow[t]{7}{*}{ Occupational status } & Housewife & 92 & 28.0 \\
\hline & Farmer & 72 & 21.9 \\
\hline & Government employee & 75 & 22.8 \\
\hline & Merchant & 37 & 11.2 \\
\hline & Student & 17 & 5.2 \\
\hline & Sex worker & 8 & 2.4 \\
\hline & Daily laborer & 28 & 8.5 \\
\hline
\end{tabular}

Note: Ethnicity others*: Tigre, Majang, Menit, Gurage.

of 200-499 cells $/ \mathrm{mm}^{3}$. Among those with comorbidity, 21 (21.2\%) had chronic heart failure, 20 (20.6\%) had urinary tract infection, and 14 (14\%) had arthritis (Figure 1). Moreover, 147 (44.7\%) of the study participants had an initial CD4 count below 200 cells $/ \mathrm{mm}^{3}, 291(88.4 \%)$ were taking TDF, 3TC, and EFV, and $240(72.9 \%)$ had a duration of disease greater than or equal to 25 months.
Two-hundred and five (62.3\%) had no family history of HIV, and all of the participants had information about the purpose of the drugs that they were taking. Most patients (84.2\%) had experienced side effects of the drugs, while $316(96.0 \%)$ did not have current side effects from the medications and $216(65.7 \%)$ were self-memorizing for taking medications. Two-hundred and eighty-five patients (86.6\%) had disclosed their HIV status to their family, and 298 (90.6\%) had not attempted any alternative treatments other than ART; the majority $(91.5 \%)$ had not had multiple sexual partners, while 288 (87.5\%) were non-drinkers and only 14 (4.3\%) were smokers (Table 2 ).

\section{Adherence Level of Participants to ART}

In this study, 274 patients $(83.3 \%)$ had adherence levels greater than or equal to $95 \%$ and were considered as adherent to ART, and $55(16.7 \%)$ were not adherent to ART (Figure 2).

\section{Factors Associated with Adherence of Patients to ART}

In bivariate logistics regression, age category, sex, residency, educational status, comorbidity, disclosure, smoking, duration of illness, WHO clinical staging, current CD4 count, and using alternative methods other than ART were significantly associated with adherence to ART care at $p<0.25$. All of these variables were moved to the multivariate logistics analysis and a significant association was considered at $p<0.05$. Multivariate logistics regression showed that patients in the age category 39-40 years old were $93 \%$ times less likely to adhere to their ART care compared to those in the age category $18-27$ years old (AOR $=0.068,95 \%$ CI $0.008,0.578$ ). Patients from urban areas who were seropositive for retroviral infections were five times more likely to adhere to ART care than patients from rural areas $(\mathrm{AOR}=5.186,95 \%$ CI 1.732, 15.529). HIV-positive patients who were unable to read and write were $90 \%$ times less likely to adhere to ART care compared to those with a higher level of education $(\mathrm{AOR}=0.097,95 \%$ CI $0.012,0.771)$. Patients who had other comorbid diseases were $96 \%$ times less likely to adhere to ART care than those without comorbid diseases (AOR $=0.042,95 \%$ CI $0.013,0.139)$. HIV-positive patients who had disclosed their HIV status to their family and others were almost four times more likely to adhere to their ART than patients who had not disclosed their status to others $(\mathrm{AOR}=3.583,95 \% \mathrm{CI} 1.008,12.739)$. The odds 


\section{Comorbidity Type}

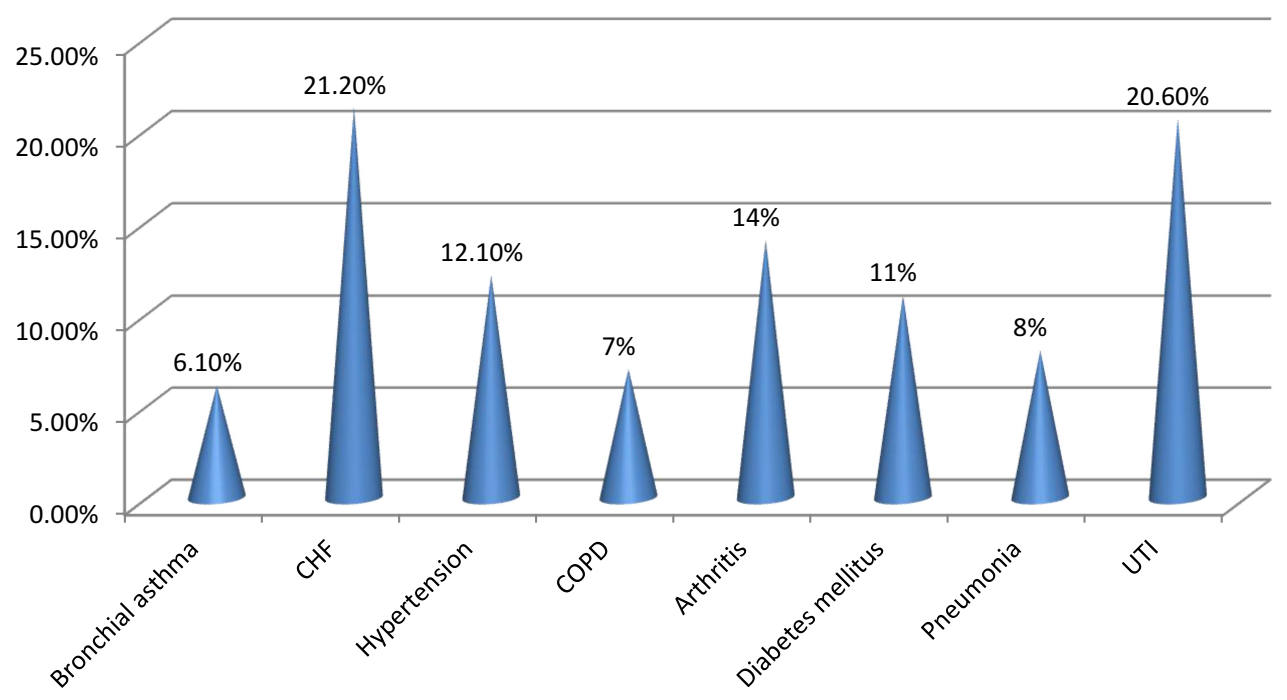

Figure I Comorbid types among patients who were on ART at GTSGH and MTUTH, southwest Ethiopia, 2020.

of adherence to ART care among WHO clinical stage II patients were $90 \%$ times lower than in WHO clinical stage I patients (AOR $=0.098,95 \%$ CI $0.021,0.453)$. The odds of adherence to ART care among patients with CD4 category $\geq 500 \mathrm{cells} / \mathrm{m}^{3}$ were almost six times higher than in patients with $\mathrm{CD} 4$ category below 200 cells $/ \mathrm{m}^{3}(\mathrm{AOR}=5.634,95 \%$ CI 1.203, 26.383) (Table 3).

\section{Discussion}

The study aimed to assess adherence to ART and its associated factors among HIV-positive patients in southwestern Ethiopia. The study identified that $83.3 \%$ of patients adhered to ART, while the remaining $16.7 \%$ adhered below the $95 \%$ adherence rate. Thus, $83.3 \%$ of patients had good adherence, $13.7 \%$ had fair adherence, and $3 \%$ had poor adherence to ART. The finding of this study, which indicated $83.3 \%$ good adherence, is lower than in studies conducted in southeastern Nigeria and Lagos Island, Nigeria, where $97.9 \%$ and $90 \%$ of patients had good adherence. ${ }^{21,22}$ The finding was also lower than in studies conducted in other regions of Ethiopia, for example $90.8 \%$ had good adherence in Gobba, ${ }^{23} 88.2 \%$ had good adherence in Gondar referral hospital, ${ }^{24}$ and 95.5\% had good adherence in Ambo. ${ }^{25}$ A possible explanation for these variations may be the difference in socioeconomic status, as the current study area is in a relatively rural part of the country compared to the other areas. This finding is, however, better than in studies done in Nigeria $(74.2 \%),{ }^{26}$ Yirgalem Hospital of Ethiopia $(63.8 \%),{ }^{27}$ and
Peru $(41.7 \%) .{ }^{28}$ The explanation for this variation, particularly from the study in Peru, may be differences in sample sizes, with a small sample being used in Peru, and differences in the tools used for assessing adherence.

The study showed that the odds of adherence to ART among patients in the age group 39-49 years old were almost 93\% times lower than in the age group 18-27 years old $(\mathrm{AOR}=0.068,95 \%$ CI $0.008,0.578)$. But there were no significant associations with adherence in other age groups, such as $28-38$ years old and $\geq 50$ years old, and most of the studies did not identify any significant associations between age group and perfect adherence. $^{21,29}$ The significantly associated age group (18-27 years) determined in this study is in contrast with a previous study in Kenya, where adherence to ART increased as the age increased, up to age $60 .^{30}$ This finding is consistent with other studies in Rwanda and Ethiopia, which stated that there was no perfect adherence in lower age groups, including 35-44 years old. ${ }^{16,31}$ The possible reason for such variation may be due to adherence in such lower age groups to counseling services given by care providers in regard to drug adherence. A considerable period for counseling in regard to ART adherence has to be given during the initiation of ART, and in this study, large numbers of participants had lived with HIV for a long time.

This study also found that the odds of adherence to ART among patients from urban areas were five times higher than in those from rural areas $(\mathrm{AOR}=5.186,95 \%$ 
Table 2 Clinical and Behavioral Characteristics of Patients Who Were on ART at GTSGH and MTUTH, Southwest Ethiopia, 2020

\begin{tabular}{|c|c|c|c|}
\hline Characteristics & Category & Frequency & Percentage \\
\hline \multirow[t]{2}{*}{ Comorbidity } & Yes & 99 & 30.1 \\
\hline & No & 230 & 69.9 \\
\hline \multirow[t]{3}{*}{ Duration of illness } & $<12$ months & 26 & 7.9 \\
\hline & $12-24$ months & 63 & 19.1 \\
\hline & $\geq 25$ months & 240 & 72.9 \\
\hline \multirow[t]{2}{*}{ Family history of HIV } & Yes & 124 & 37.7 \\
\hline & No & 205 & 62.3 \\
\hline \multirow[t]{3}{*}{ Current WHO clinical stage } & I & 296 & 90.0 \\
\hline & II & 24 & 7.3 \\
\hline & III & 9 & 2.7 \\
\hline \multirow[t]{3}{*}{ Initial CD4 category } & $<200$ cells $/ \mathrm{mm}^{3}$ & 147 & 44.7 \\
\hline & $200-499$ cells $/ \mathrm{mm}^{3}$ & 142 & 43.2 \\
\hline & $\geq 500$ cells $/ \mathrm{mm}^{3}$ & 40 & 12.2 \\
\hline \multirow[t]{3}{*}{ Current CD4 category } & $<200$ cells $/ \mathrm{mm}^{3}$ & 53 & 16.1 \\
\hline & $200-499$ cells $/ \mathrm{mm}^{3}$ & 151 & 45.9 \\
\hline & $\geq 500$ cells $/ \mathrm{mm}^{3}$ & 125 & 38.0 \\
\hline \multirow{2}{*}{ Ever had side effects of ART } & Yes & 277 & 84.2 \\
\hline & No & 52 & 15.8 \\
\hline \multirow[t]{2}{*}{ Current side effects of ART } & Yes & 13 & 4.0 \\
\hline & No & 316 & 96.0 \\
\hline \multirow[t]{4}{*}{ Current ART regimen } & TDF, 3TC, EFV & 291 & 88.4 \\
\hline & TDF, 3TC, NVP & 8 & 2.4 \\
\hline & AZT, 3TC, NVP & 17 & 5.2 \\
\hline & AZT, 3TC, EFV & 13 & 3.9 \\
\hline \multirow[t]{4}{*}{ Who reminds to take ART } & Self & 216 & 65.7 \\
\hline & Alarm & 78 & 23.7 \\
\hline & Family members & 19 & 5.8 \\
\hline & Radio/television & 16 & 4.9 \\
\hline \multirow[t]{2}{*}{ Treatment other than ART } & Yes & 31 & 9.4 \\
\hline & No & 298 & 90.6 \\
\hline \multirow[t]{2}{*}{ Treatment other than ART } & Traditional drug & 12 & 38.7 \\
\hline & Religious practice, eg, Tsebel & 19 & 61.3 \\
\hline \multirow[t]{2}{*}{ Disclosure to family/others } & Yes & 285 & 86.6 \\
\hline & No & 44 & 13.4 \\
\hline \multirow[t]{2}{*}{ Current smoking } & Yes & 14 & 4.3 \\
\hline & No & 315 & 95.7 \\
\hline \multirow[t]{2}{*}{ Current alcohol drinking } & Yes & 41 & 12.5 \\
\hline & No & 288 & 87.5 \\
\hline \multirow[t]{2}{*}{ Ever had multiple sexual partners } & Yes & 28 & 8.5 \\
\hline & No & 301 & 91.5 \\
\hline
\end{tabular}

Abbreviations: TDF, tenofovir; 3TC, lamivudine; EFV, efavirenz; NVP, nevirapine; AZT, zidovudine. 


\section{Adherence Level}

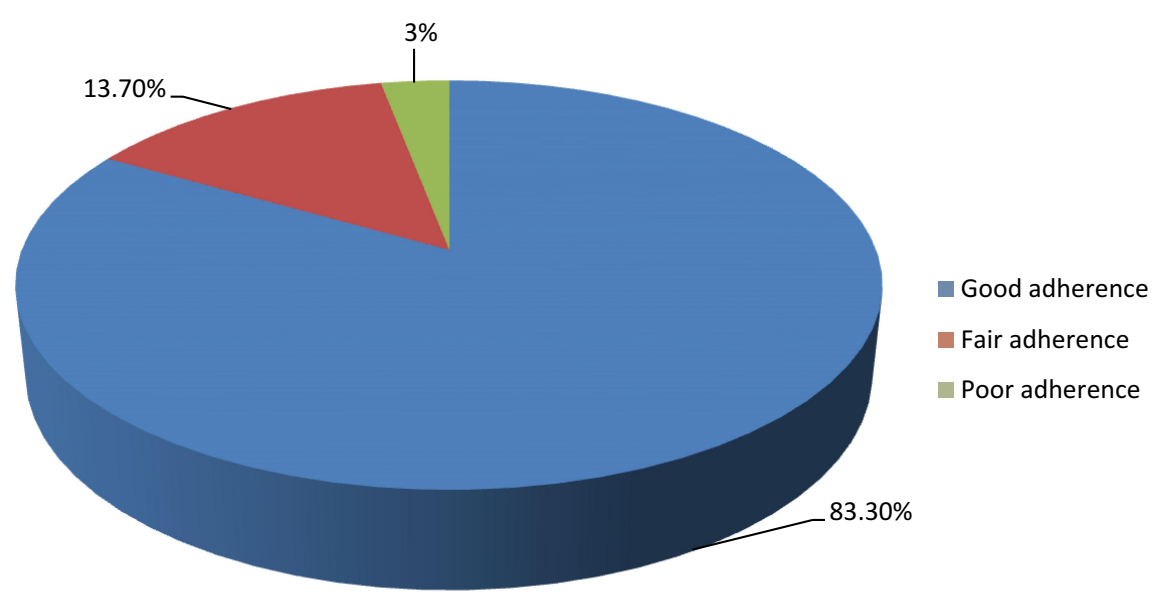

Figure 2 Adherence levels of patients to ART at GTSGH and MTUTH, southwest Ethiopia, 2020.

CI $1.732,15.529)$. This is consistent with the study conducted in Gondar. ${ }^{23}$ The justification for this finding may be that patients from urban areas have easy access to information about the importance of strict adherence to ART, and such patients may have good educational status. The justification given in regard to education could be that patients with good educational status are better at adhering than those with poor educational status, and it is clear that individuals with good educational status live in urban areas of Ethiopia. The study also identified that the odds of adherence among HIV-positive patients who were unable to write and read were almost $90 \%$ times lower compared to those HIV-positive patients with higher educational status. Similarly, the odds of adherence among HIV-positive patients who were able to write and read were almost $94 \%$ times lower compared to those HIVpositive patients with higher educational status. This is consistent with a study from Harari, Ethiopia. ${ }^{16}$

The study pointed out that patients with other comorbid diseases were almost $96 \%$ times less likely to adhere to ART care than those without comorbid diseases $(\mathrm{AOR}=0$. $042,95 \%$ CI $0.013,0.139)$. This finding is supported by a study from Gondar. ${ }^{23}$ Patients with multiple health problems may miss their daily drugs to avoid the selfperceived side effects of taking many medications. Being tired of comorbid disease conditions may limit patients from taking ART drugs. ${ }^{32}$ The study also identified that HIV-positive patients who disclosed their HIV status to their family and others were almost four times more likely to adhere to their ART than patients who did not disclose their status to others $(\mathrm{AOR}=3.583,95 \% \mathrm{CI} 1.008,12.739)$. This is supported by the findings of a meta-analysis ${ }^{33}$ and a study from Nigeria. ${ }^{34}$ A possible reason for this association is that patients who have disclosed their status to their family can take their medications without fear, with good social support and appropriate financial support from their family $^{35}$

This study also showed that the odds of adherence among patients with WHO clinical stage II were 90\% lower than in those with WHO clinical stage I. Similarly, the odds of adherence among patients with WHO clinical stage III were $99 \%$ lower than in those with WHO stage I. This finding is not in line with a study conducted in northeast Ethiopia, in which there was no significant association between WHO clinical staging and adherence status. ${ }^{36}$ The study also found that patients with a current CD4 category greater than or equal to 500 cells $/ \mathrm{mm}^{3}$ were five times more adherent than those with CD4 of below 200 cells $/ \mathrm{mm}^{3}$. This is supported by other studies, which found that strict adherence can bring about immune reconstitution and rebuilding. ${ }^{23,37-40}$

\section{Limitations}

The study was purely quantitative and did not assess the factors that affected adherence through qualitative study. Therefore, a qualitative study is recommended. The present study also only identified factors associated with the adherence but did not assess causality. Therefore, instrumental variable analysis is recommended to illustrate causality and improve the management of HIV-positive patients. 
Table 3 Bivariate and Multivariate Logistic Regression Analysis for Factors Associated with Adherence to ART Among Patients in GTSGH and MTUTH, Southwest Ethiopia, 2020

\begin{tabular}{|c|c|c|c|c|c|}
\hline \multirow[t]{2}{*}{ Variables } & \multirow[t]{2}{*}{ Category } & \multicolumn{2}{|c|}{$\begin{array}{l}\text { Adherence Status to ART } \\
\text { Care }\end{array}$} & \multirow[t]{2}{*}{ COR $(95 \% \mathrm{Cl})$} & \multirow[t]{2}{*}{ AOR $(95 \% \mathrm{Cl})$} \\
\hline & & $\begin{array}{l}\text { Non-Adherent } \\
\text { (\%) }\end{array}$ & $\begin{array}{l}\text { Adherent } \\
\text { (\%) }\end{array}$ & & \\
\hline Age category & $\begin{array}{l}18-27 \\
28-38 \\
39-49 \\
\geq 50\end{array}$ & $\begin{array}{l}4(7 \%) \\
19(34.5 \%) \\
31(56.4 \%) \\
1(1.8 \%)\end{array}$ & $\begin{array}{l}69(25.2 \%) \\
125(45.6 \%) \\
55(20.1 \%) \\
25(9.1 \%)\end{array}$ & $\begin{array}{l}\text { I (ref.) } \\
0.38 \text { I }(0.125,1.166) \\
0.103(0.034,0.309)^{*} \\
\text { I.449 }(0.155,13.594)\end{array}$ & $\begin{array}{l}\text { I (ref.) } \\
0.836(0.108,6.501) \\
0.068(0.008,0.578)^{* *} \\
8.107(0.190,346.524)\end{array}$ \\
\hline Sex & $\begin{array}{l}\text { Male } \\
\text { Female }\end{array}$ & $\begin{array}{l}35(63.6 \%) \\
20(36.4 \%)\end{array}$ & $\begin{array}{l}\mid 23(44.9 \%) \\
15 \mid(55.1 \%)\end{array}$ & $\begin{array}{l}\text { I (ref.) } \\
2.148(1.181,3.910)^{*}\end{array}$ & $\begin{array}{l}\text { I (ref.) } \\
2.543(0.885,7.306)\end{array}$ \\
\hline Residence & $\begin{array}{l}\text { Urban } \\
\text { Rural }\end{array}$ & $\begin{array}{l}24(43.6 \%) \\
31(56.4 \%)\end{array}$ & $\begin{array}{l}230(83.9 \%) \\
44(16.1 \%)\end{array}$ & $\begin{array}{l}6.752(3.622,12.588)^{*} \\
\text { I (ref.) }\end{array}$ & $\begin{array}{l}5.186(1.732,15.529)^{* *} \\
\text { I (ref.) }\end{array}$ \\
\hline Educational status & $\begin{array}{l}\text { Unable to read and write } \\
\text { Able to write and read without formal education } \\
\text { Primary education } \\
\text { Secondary education } \\
\text { Higher education }\end{array}$ & $\begin{array}{l}21(38.2 \%) \\
13(23.6 \%) \\
11(20 \%) \\
7(12.7 \%) \\
3(5.5 \%)\end{array}$ & $\begin{array}{l}36(13.1 \%) \\
22(8 \%) \\
144(52.6 \%) \\
50(18.2 \%) \\
22(8.1 \%)\end{array}$ & $\begin{array}{l}0.234(0.062,0.876)^{*} \\
0.23 \mathrm{I}(0.058,0.924)^{*} \\
\mathrm{I} .785(0.46 \mathrm{I}, 6.908) \\
0.974(0.230,4.12 \mathrm{I}) \\
\mathrm{I} \text { (ref.) }\end{array}$ & $\begin{array}{l}0.097(0.012,0.771)^{* *} \\
0.056(0.006,0.532)^{* *} \\
0.902(0.126,6.45 \mathrm{I}) \\
0.216(0.019,2.46 \mathrm{I}) \\
\mathrm{I} \text { (ref.) }\end{array}$ \\
\hline Smoking & $\begin{array}{l}\text { Yes } \\
\text { No }\end{array}$ & $\begin{array}{l}4(7.3 \%) \\
51(92.7 \%)\end{array}$ & $\begin{array}{l}10(3.6 \%) \\
264(96.4 \%)\end{array}$ & $\begin{array}{l}0.483(0.146,1.600)^{*} \\
\text { I (ref.) }\end{array}$ & $\begin{array}{l}0.8 I I(0.081,8.097) \\
\text { I (ref.) }\end{array}$ \\
\hline Duration of illness & $\begin{array}{l}<12 \text { months } \\
12-24 \text { months } \\
\geq 25 \text { months }\end{array}$ & $\begin{array}{l}2(3.6 \%) \\
12(21.8 \%) \\
4 \mid(74.6 \%)\end{array}$ & $\begin{array}{l}24(8.7 \%) \\
51(18.7 \%) \\
199(72.6 \%)\end{array}$ & $\begin{array}{l}\text { I (ref.) } \\
0.354(0.073,1.709)^{*} \\
0.404(0.092, \quad \text { I.779)* }\end{array}$ & $\begin{array}{l}\text { I (ref.) } \\
0.240(0.007,8.069) \\
0.198(0.007,5.359)\end{array}$ \\
\hline Comorbidity & $\begin{array}{l}\text { Yes } \\
\text { No }\end{array}$ & $\begin{array}{l}43(78.2 \%) \\
12(21.8 \%)\end{array}$ & $\begin{array}{l}56(20.4 \%) \\
218(79.6 \%)\end{array}$ & $\begin{array}{l}0.072(0.035,0.145)^{*} \\
\text { I (ref.) }\end{array}$ & $\begin{array}{l}0.042(0.013,0.139)^{* *} \\
\text { I (ref.) }\end{array}$ \\
\hline Disclosure of HIV & $\begin{array}{l}\text { Yes } \\
\text { No }\end{array}$ & $\begin{array}{l}39(70.9 \%) \\
16(29.1 \%)\end{array}$ & $\begin{array}{l}246(89.8 \%) \\
28(10.2 \%)\end{array}$ & $\begin{array}{l}3.604(1.788,7.266)^{*} \\
\text { I (ref.) }\end{array}$ & $\begin{array}{l}3.583(1.008,12.739)^{* *} \\
\text { I (ref.) }\end{array}$ \\
\hline WHO clinical stage & $\begin{array}{l}\text { Stage I } \\
\text { Stage II } \\
\text { Stage III }\end{array}$ & $\begin{array}{l}36(65.5 \%) \\
13(23.6 \%) \\
6(10.8 \%)\end{array}$ & $\begin{array}{l}260(94.9 \%) \\
11(4 \%) \\
3(1.1 \%)\end{array}$ & $\begin{array}{l}\text { I (ref.) } \\
0.117(0.049,0.28 I)^{*} \\
0.069(0.017,0.289)^{*}\end{array}$ & $\begin{array}{l}\text { I (ref.) } \\
0.098(0.02 \mathrm{I}, 0.453)^{* *} \\
0.004(0.00 \mathrm{I}, 0.075)^{* *}\end{array}$ \\
\hline Current CD4 category & $\begin{array}{l}<200 \text { cells } / \mathrm{mm}^{3} \\
200-499 \text { cells } / \mathrm{mm}^{3} \\
\geq 500 \text { cells } / \mathrm{mm}^{3}\end{array}$ & $\begin{array}{l}13(23.6 \%) \\
29(52.7 \%) \\
13(23.6 \%)\end{array}$ & $\begin{array}{l}40(14.6 \%) \\
122(44.5 \%) \\
112(40.9 \%)\end{array}$ & $\begin{array}{l}\text { I (ref.) } \\
\text { I.367 }(0.649,2.88 \mathrm{I}) \\
2.800(\mathrm{I} .198,6.546)^{*}\end{array}$ & $\begin{array}{l}\text { I (ref.) } \\
0.853(0.237,3.066) \\
5.634(1.203,26.383)^{* *}\end{array}$ \\
\hline $\begin{array}{l}\text { Treatment other than } \\
\text { ART }\end{array}$ & $\begin{array}{l}\text { Yes } \\
\text { No }\end{array}$ & $\begin{array}{l}13(23.6 \%) \\
42(76.4 \%)\end{array}$ & $\begin{array}{l}18(6.6 \%) \\
256(93.4 \%)\end{array}$ & $\begin{array}{l}0.227(0.104,0.498)^{*} \\
\text { I (ref.) }\end{array}$ & $\begin{array}{l}\text { I. } 16 \mathrm{I}(0.277,4.86 \mathrm{I}) \\
\mathrm{I} \text { (ref.) }\end{array}$ \\
\hline
\end{tabular}

Notes: *Significantly associated at $p<0.25$; **significantly associated at $p<0.05$.

Abbreviations: AOR, adjusted odds ratio; ART, antiretroviral therapy; COR, crude odds ratio; Cl, confidence interval; CD4, cluster of differentiation 4; HIV, human immunodeficiency virus.

\section{Conclusions}

The adherence level of patients to ART is good, even if it was below that found in other studies conducted in other regions of Ethiopia. Being in the age group 39-49 years, educational status, comorbidity, and WHO clinical staging were negatively associated with ART adherence. Residency, disclosure, and current CD4 categories greater than or equal to 500 cells $/ \mathrm{mm}^{3}$ were positively associated with adherence. Good counseling, particularly to patients from rural areas, those with low educational status, and those with lower CD4 counts, and counseling on the importance of disclosure, is recommended and should be given by professionals during care at the ART clinic.

\section{Acknowledgments}

We are very grateful to all study participants for their commitment in responding to questionnaires and all data collectors for their collaboration up to the end of the study. 


\section{Author Contributions}

All authors made a significant contribution to the work reported, whether that is in the conception, study design, execution, acquisition of data, analysis, and interpretation, or in all these areas; took part in drafting, revising, or critically reviewing the article; gave final approval of the version to be published; have agreed on the journal to which the article has been submitted; and agree to be accountable for all aspects of the work.

\section{Disclosure}

The authors declare that they have no competing interests.

\section{References}

1. UNAIDS Science Panel. Making the End of AIDS Real: Consensus Building Around What We Mean by "Epidemic Control". Geneva: UNAIDS; 2018. Available from: http://www.unaids.org/sites/default/files/ media_asset/glion_oct2017_meeting_report_en.pdf. Accessed 4 July 2019.

2. Joint United Nation program on HIV/AIDS (UNAIDS). Prevention Gap Report. Geneva: unaids.org; 2016.

3. HAPCO. HIV prevention in Ethiopia National Road map; 2018. https://ethiopia.unfpa.org/en/hiv-prevention-ethiopia-national-roadmap. Available from:Accessed 25 September 2018.

4. Joint United Nations Programme on HIV/AIDS. United Nation AIDS World AIDS Day Report 2011 (Faster, Smarter, Better). Geneva: UNAIDS; 2011.

5. Steel G, Nwokike J, Joshi MP. Development of a Multi-Method Tool to Measure ART Adherence in Resource-Constrained Settings: The South Africa Experience. RPM Plus. Arlington, VA: Management Sciences for Health; 2007.

6. Morowatisharifabad MA, Movahed E, Nikooie R, et al. Adherence to medication and physical activity among people living with HIV/ AIDS. Iran J Nurs Midwifery Res. 2019;24(5):397.

7. Mills EJ, Nachega JB, Buchan I, et al. Adherence to antiretroviral therapy in sub-Saharan Africa and North America: a meta-analysis. JAMA. 2006;296(6):679-690. doi:10.1001/jama.296.6.679

8. Juday T, Gupta S, Grimm K, Wagner S, Kim E. Factors associated with complete adherence to HIV combination antiretroviral therapy. HIV Clin Trials. 2011;12(2):71-78. doi:10.1310/hct1202-71

9. Mills EJ, Nachega JB, Bangsberg DR, et al. Adherence to HAART: a systematic review of developed and developing nation patient-reported barriers and facilitators. PLoS Med. 2006;3(11): e438. doi:10.1371/journal.pmed.0030438

10. Falagas ME, Zarkadoulia EA, Pliatsika PA, Panos G. Socioeconomic status (SES) as a determinant of adherence to treatment in HIV infected patients: a systematic review of the literature. Retrovirology. 2008;5(1):13. doi:10.1186/1742-4690-5-13

11. Atkinson MJ, Petrozzino JJ. An evidence-based review of treatment-related determinants of patients' nonadherence to HIV medications. AIDS Patient Care STDS. 2009;23(11):903-914. doi:10.1089/apc.2009.0024

12. Arrivillaga M, Ross M, Useche B, Alzate ML, Correa D. Social position, gender role, and treatment adherence among Colombian women living with HIV/AIDS: social determinants of health approach. Rev Panam Salud Publica. 2009;26(6):502-510. doi:10.1590/S1020-49892009001200005

13. Asmare M, Aychiluhem M, Ayana M, Jara D. Level of ART adherence and associated factors among HIV sero-positive adult on highly active antiretroviral therapy in Debre Markos Referral Hospital, Northwest Ethiopia. $J$ Antivir Antiretrovir. 2014;6:120-126. doi:10.4172/jaa. 10000107
14. Cohen MS, Chen YQ, McCauley M, et al. HPTN 052 Study Team. Prevention of HIV-1 infection with early antiretroviral therapy. N Engl J Med. 2011;365(6):493-505. doi:10.1056/NEJMoa1105243

15. Baggaley RF, White RG, Hollingsworth TD, Boily MC. Heterosexual HIV-1 infectiousness and antiretroviral use: systematic review of prospective studies of discordant couples. Epidemiology. 2013;24 (1):110-121. doi:10.1097/EDE.0b013e318276cad7

16. Mitiku H, Abdosh T, Teklemariam Z. Factors affecting adherence to antiretroviral treatment in Harari National Regional State, Eastern Ethiopia. ISRN AIDS. 2013;2013:960954.

17. Berhe B, Yigzaw K, Melaku K, Desalegn T, Mebrahtu A, Yalemzewod A. Determinants to antiretroviral treatment non-adherence among adult HIV/ AIDS patients in northern Ethiopia. AIDS Res Ther. 2017;14:16.

18. Kaplan JE, Benson C, Holmes KK, Brooks JT, Pau A, Masur H. Centers for Disease Control and Prevention (CDC), National Institutes of Health, HIV Medicine Association of the Infectious Diseases Society of America. Guidelines for prevention and treatment of opportunistic infections in HIV-infected adults and adolescents. MMWR Recomm Rep. 2009;58(RR-4):1-207.

19. Machtinger EL, Bangsberg DR Adherence to HIV antiretroviral therapy HIV InSite Knowledge Base chapter. 2006.

20. Federal Ministry of Health (FMOH) Ethiopia. National Consolidated Guidelines for Comprehensive Hiv Prevention, Care and Treatment. Addis Ababa: FMOH Ethiopia; 2018.

21. Ugochukwu U, Onyeonoro UUEU, Ibeh CC, Nwamoh UN, Ukegbu AU, Emelumadu OF. Adherence to antiretroviral therapy among people living with human immunodeficiency virus/acquired immunodeficiency syndrome in a tertiary health facility in South Eastern Nigeria. J HIV Hum. 2013;1(2):58-63.

22. Adekemi O, Sekoni OR, Obidik BM. Stigma, medication adherence and coping mechanism among people living with HIV attending General Hospital, Lagos Island, Nigeria. Prm Health Care Fam. 2012;1-8.

23. Molla AA, Gelagay AA, Mekonnen HS, Teshome D. Adherence to antiretroviral therapy and associated factors among HIV positive adults attending care and treatment in University of Gondar Referral Hospital, Northwest Ethiopia. BMC Infect Dis. 2018;18 (1):266. doi:10.1186/s12879-018-3176-8.24

24. Teshome W, Belayneh M, Moges M, et al. Who Takes the Medicine? Adherence to Antiretroviral Therapy in Southern Ethiopia. Vol. 2015. Dove Medical Press Limited; 2015:1531-1537. doi: 10.2147/PPA.S9081.

25. Fituma S, Tsegaye D. Antiretroviral therapy adherence among people living with HIV In Ambo Hospital, West Shewa Zone, Oromia Region, Ethiopia. Obstet Gynecol Int J. 2016;5(Issue 2):1-9.

26. Moses Kayode $\mathrm{O}$, et al. Investigation of factors affecting medication adherence among people living with HIV/AIDS under Non-Governmental Organizations in Ibadan City, Nigeria. JPBMS. 2012;21(21):1-5.

27. Markos E, Worku A, Davey G. Adherence to ART in PLWHA at Yirgalem Hospital, SouthEthiopia. Ethiop J Health Dev. 2008;22:2.

28. Leyva-Moral JM, Loayza-Enriquez BK, Palmieri PA, et al. Adherence to antiretroviral therapy and the associated factors among people living with HIV/AIDS in Northern Peru: a cross-sectional study. AIDS Res Ther. 2019;16:22. doi:10.1186/ s12981-019-0238-y

29. Abera A, Fenti B, Tesfaye T, Balcha F. Factors Influencing adherence to antiretroviral therapy among people living with HIV/AIDS at art clinic in Jimma University Teaching Hospital, Southwest Ethiopia. $J$ Pharma. 2015;1(1):2-6.

30. Anthony $\mathrm{N}$ Factors that influence non-adherence to antiretroviral therapy among HIV and AIDs patients in central province, Kenya; 2011. Available from: http://ir-library.ku.ac.ke/handle/123456789/ 1725. Accessed August 21, 2020.

31. Elul B, Basinga P, Nuwagaba-Biribonwoha H, et al. High levels of adherence and viral suppression in a nationally representative sample of HIV-infected adults on antiretroviral therapy for 6,12 and 18 months in Rwanda. PLoS One. 2013;8(1):e53586. doi:10.1371/journal.pone. 0053586 
32. Kranzer K, Ford N. Unstructured treatment interruption of antiretroviral therapy in clinical practice: a systematic review. Tropical Med Int Health. 2011;16:1297-1313.

33. Dessie G, Wagnew F, Mulugeta H, et al. The effect of disclosure on adherence to antiretroviral therapy among adults living with HIV in Ethiopia: a systematic review and meta-analysis. BMC Infect Dis. 2019;19:528. doi:10.1186/s12879-019-4148-3

34. Pennap GR, Abdullahi U, Bako IA. Adherence to highly active antiretroviral therapy and its challenges in people living with human immunodeficiency virus (HIV) infection in Keffi, Nigeria. JAHR. 2013;5(2):52-58.

35. Tshweneagae GT, Oss VM, Mgutshini T. Disclosure of HIV status to sexual partners by people living with HIV. curationis. 2015;38(1):1-6.

36. Mengistie A, Birhane A, Tesfahun E. Assessment of adherence to antiretroviral therapy among adult people living with HIV/AIDS in North East, Ethiopia. Appl Microb Res. 2019;2(2):21-27.
37. Fonsah JY, Njamnshi AK, Kouanfack C, et al. Adherence to antire troviral therapy (ART) in yaounde'-cameroon: association with opportunistic infections, depression, ART regimen and side effects. PLoS One. 2017;12(1):e0170893. doi:10.1371/journal.pone.0170893

38. Wang H, Zhou J, Zhou J, et al. Consistent ART adherence is associated with improved quality of life, CD4 counts, and reduced tal costs in Central China. AIDS Res Hum Retrovir. 2009;25(8):757-763. doi:10.1089/aid.2008.0173

39. Nachega J, Morroni CR, Efron GR, Ram M. Impact of immune reconstitution inflammatory syndrome on antiretroviral therapy adherence. Patient Prefer Adherence. 2012;6:887-891. doi:10.2147/PPA.S38897

40. Dhasmana DJ, Dheda K, Ravn P, et al. Immune reconstitution inflammatory syndrome in HIV-infected patients receiving antiretroviral therapy. Drugs. 2008;68:191-208. doi:10.2165/00003495200868020-00004

\section{Publish your work in this journal}

Patient Preference and Adherence is an international, peer-reviewed, open access journal that focusing on the growing importance of patient preference and adherence throughout the therapeutic continuum. Patient satisfaction, acceptability, quality of life, compliance, persistence and their role in developing new therapeutic modalities and compounds to optimize clinical outcomes for existing disease states are major areas of interest for the journal. This journal has been accepted for indexing on PubMed Central. The manuscript management system is completely online and includes a very quick and fair peer-review system, which is all easy to use. Visit http:// www.dovepress.com/testimonials.php to read real quotes from published authors. 